\title{
Physiological, phenological and productive responses of tomato (Solanum licopersicum L.) plants treated with QuitoMax.
}

\author{
Juan J. Reyes-Pérez ${ }^{1,2}$, Emmanuel A. Enríquez-Acosta², Bernardo Murillo- \\ Amador ${ }^{3}$, Miguel A. Ramírez-Arrebato ${ }^{4}$, Aida T. Rodríguez-Pedroso ${ }^{4}$, \\ Liliana Lara-Capistrán ${ }^{5}$, and Luis G. Hernández-Montiel ${ }^{3}$
}

${ }^{1}$ Universidad Técnica Estatal de Quevedo. Av. Walter Andrade. Km 1.5 vía a Santo Domingo. Quevedo, Los Ríos, Ecuador.

${ }^{2}$ Universidad Técnica de Cotopaxi. Extensión La Maná. Av. Los Almendros y Pujilí, Edificio Universitario, La Maná, Ecuador.

${ }^{3}$ Centro de Investigaciones Biológicas del Noroeste S.C., Instituto Politécnico Nacional No. 195. Colonia

Playa Palo de Santa Rita Sur, La Paz, Baja California Sur, México.

${ }^{4}$ Unidad Científico Tecnológica de Base los Palacios, Pinar del Río perteneciente al Instituto Nacional de Ciencias Agrícolas (INCA), Cuba.

${ }^{5}$ Universidad Veracruzana Campus Xalapa, Facultad de Ciencias Agrícolas. Circuito Universitario Gonzalo Aguirre Beltrán s/n, Zona Universitaria. Xalapa, Veracruz, México.

\begin{abstract}
J.J. Reyes-Pérez, E.A. Enríquez-Acosta, B. Murillo-Amador, M.A. Ramírez-Arrebato, A.T. Rodríguez-Pedroso, R. Zulueta-Rodríguez, and L.G. Hernández-Montiel. Physiological, phenological and productive responses of tomato (Solanum licopersicum L.) plants treated with QuitoMax. 2018. Cien. Inv. Agr. 45(2): 120-127. The objective of this study was to evaluate the foliar application of the biostimulant QuitoMax at concentrations 100, 200, 300 and $400 \mathrm{mg} \cdot \mathrm{ha}^{-1}$ in comparison to a control without the application of QuitoMax on the height and stem thickness of tomato plants. The durations of the plant phenological phases, productive indicators (the number of fruit, bunches per plant, the number of fruits per bunches, the polar and equatorial diameters of the fruit, the mass of the fruit and crop yield), the quality of the fruit expressed as the total soluble solids and acidity, and the commercial quality of the harvested fruits were also evaluated. The highest concentrations of QuitoMax (300 and $400 \mathrm{mg} \cdot \mathrm{ha}^{-1}$ ) were found to produce the most vigorous plants, lengthened the duration of the plant phenophases, and resulted in significantly higher values in the production indicators, including the fresh mass of the fruits and performance. Additionally, they produced fruits with a higher content of total soluble solids.
\end{abstract}

Key words: Biostimulant, chitosan, vegetable. 


\section{Introduction}

Tomato (Solanum licopersicum L.) is much appreciated and can be consumed either fresh or after being processed. It is estimated that global production reached 130 million tons in 2016 (Freshplaza, 2016). However, most of the production is obtained under a system of intensive production, with the high use of agrochemicals that can damage human health and the environment (FAO, 1997).

The use of environmentally friendly alternatives in current agricultural production is a priority for modern agriculture (Espinosa and Molina, 2015). As a result, organic fertilizers and beneficial microorganisms, such as mycorrhizae, among other alternatives, have been applied in tomato production (Márquez-Hernández et al., 2013; Durand et al., 2013).

However, recent studies have shown that the application of biostimulants is an attractive and viable alternative in agriculture (Pichyangkuraa and Chadchawanb, 2015, Díaz-Leguizamón et al., 2016). Among these compounds is chitosan, which is obtained from the exoskeleton of crustaceans. Chitosan has different modes of action, including the inhibition of the growth of fungi and bacteria in vitro and in vivo (Rodríguez-Pedroso et al., 2016). In addition, chitosan stimulates enzymes and other metabolites in plants and the growth and development of crops (Malerba and Cerana, 2016). QuitoMax is a liquid formulation based on chitosan $\left(4 \mathrm{~g} . \mathrm{L}^{-1}\right.$, $0.5 \%$ acetic acid and $0.07 \%$ potassium ions). It has shown high performance in producing stimulating effects in different crops, such as potatoes and beans (Morales et al., 2015; 2016). Therefore, the aim of this study was to evaluate the effects of different concentrations of QuitoMax on the phenological, physiological and productive indicators of tomato var. Pomodoro, a commercial variety.

\section{Materials and methods}

This study was carried out at the "La Playita" Experimental Center of the Technical Univer- sity of Cotopaxi, La Maná, in the province of Cotopaxi, La Maná, Ecuador. The maximum and minimum temperatures at the site were 23 and $17{ }^{\circ} \mathrm{C}$, respectively, with a relative humidity of $86.83 \%$, an average annual precipitation of $3029.30 \mathrm{~mm}$ and 735.70 light hours year ${ }^{-1}$. Seeds of the Pomodoro tomato variety from the Agripac company were used to obtain the seedlings. The seeds were planted in 200-well polyethylene trays that contained Sogemix ${ }^{\circledR}$ moss (PROMIX, Premier Tech, Canada) as a substrate. The irrigation applied to the trays was carried out daily in order to achieve the homogenous emergence of the plants. Then, in a second stage, it was carried out under shaded mesh conditions in a structure that is located at the "La Playita" Experimental Center. The plants were transplanted into $1 \mathrm{~kg}$ bags when they had an average height of between 10 and $15 \mathrm{~cm}$; the bags contained a mixture in a 1:1 ratio of course sterile sand plus the same commercial substrate we used in the trays as a substrate. Two plants were placed in each bag to ensure the success of the transplantation process. After the plants were transplanted, irrigation was applied daily using sterile water. QuitoMax was obtained from the National Institute of Agricultural Sciences of Cuba. The treatments consisted of a control and the application of a foliar spray of QuitoMax to the plants early in the morning (8:00 AM) at concentrations of 100, 200, and $300 \mathrm{mg} \mathrm{ha}^{-1} 20$ days after they were transplanted and at the beginning of flowering (25 days after transplantation).

The height of the plants $(\mathrm{cm})$ was evaluated using a millimeter tape, and the thickness of the stems (cm) was determined using a Vernier caliper. In addition, the durations of the phenological phases (in days) of the tomato plants treated with QuitoMax at different concentrations were evaluated. Additionally, all the treatments and their replicates were evaluated in terms of the following variables: the number of bunches per plant, number of fruits per bunch, polar and equatorial diameters of the fruit (in centimeters; measured using a millimeter tape), mass of the 
fruit (in grams; measured using a technical balance), and agricultural yield.

Fruit quality indicators, such as the content of total soluble solids and acidity, were also evaluated, as well as the fruits from different treatments were classified according to their commercial quality into first, second, and third quality groups and expressed as fruit mass. All measurements were done according to the procedure established in Ecuador (NTE, 2014).

\section{Statistical analysis}

The experimental data were processed using one-way analysis of variance (ANOVA) for each variable evaluated, and Tukey's HSD test $(p=0.05)$ was used for the multiple comparison of means when significant differences among treatments were detected. The statistical analyses were carried out using the program Statistica v. 10.0 for Windows (StatSoft, Inc., 2011).

\section{Results and discussion}

The foliar application of QuitoMax at different concentrations caused significant differences among the treatments in terms of the tomato plant growth variables: height and the thickness of the stem (Table 1).

Table 1. Height and thickness of the stem of tomato plants treated with QuitoMax at different concentrations.

\begin{tabular}{lcc}
\hline $\begin{array}{l}\text { QuitoMax treatments } \\
\left(\mathrm{mg} \mathrm{ha}^{-1}\right)\end{array}$ & $\begin{array}{c}\text { Height of the } \\
\text { plant }(\mathrm{cm})\end{array}$ & $\begin{array}{c}\text { Stem thickness } \\
(\mathrm{mm})\end{array}$ \\
\hline Control & $42.3 \mathrm{~b}$ & $13.3 \mathrm{~b}$ \\
100 & $42.6 \mathrm{~b}$ & $14.0 \mathrm{~b}$ \\
200 & $43.3 \mathrm{~b}$ & $14.3 \mathrm{~b}$ \\
300 & $45.3 \mathrm{a}$ & $15.6 \mathrm{ab}$ \\
400 & $45.6 \mathrm{a}$ & $17.6 \mathrm{a}$ \\
$\mathrm{CV}(\%)$ & 3.41 & 8.66 \\
\hline
\end{tabular}

Values within the same column with same letter are not significantly different at $p=0.05$ (Tukey's HSD multiple range test).
The highest concentrations of QuitoMax applied (300 and $400 \mathrm{mg} \mathrm{ha}^{-1}$ ) significantly stimulated the plants, causing them to grow taller than the plants in the other treatments. It should be noted that the plants treated with the lower concentrations (100 and $200 \mathrm{mg} \mathrm{ha}^{-1}$ ) did not show differences from those in the control treatment. Similarly, in the case of stem thickness, the lower concentrations and the $300 \mathrm{mg} \mathrm{ha}^{-1}$ concentration did not differ from the control. However, the plants that received the application of the concentration of $400 \mathrm{mg} \mathrm{ha}^{-1}$ were always significantly taller and had stems that were thicker than those in the rest of the treatments except the $300 \mathrm{mg} \mathrm{ha}^{-1}$ concentration treatment.

These results can be explained by taking into account that chitosan, the active ingredient of QuitoMax, has been recognized as a plant growth biostimulant (Pichyangkuraa and Chadchawanb, 2015). Its activity has been related to significant chlorophyll content increases in leaves as a result of chitosan application. These increases in the chlorophyll content in leaves may be caused by the enhanced uptake of nutrients by plants, which is affected by the chitosan concentration (Salachna and Zawadzińska, 2014).

The results also agree with those found by Martínez et al. (2007), who found stimulation of the growth of tomato var. Amalia plants treated with chitosan, the active ingredient of QuitoMax, but applied to the seeds. Other authors (RodríguezPedroso et al., 2017) have also reported that the application of chitosan stimulates the growth of rice crops, with an increase in root length even under saline conditions, which is related to the greater activation of the antioxidant systems of the plants.

Furthermore, the durations of the phenological phases of the tomato plants were also affected when they were treated with different concentrations of QuitoMax (Table 2). When the product was not applied to the seeds, there were no dif- 
Table 2. Duration of the phenological phases of tomato plants treated with QuitoMax at different concentrations.

\begin{tabular}{lccccc}
\hline & \multicolumn{3}{c}{ Phenological phases (days) } \\
\hline $\begin{array}{l}\text { QuitoMax } \\
\text { treatments }\left(\mathrm{mg} \mathrm{ha}^{-1}\right)\end{array}$ & S to MG & MG to MF & MF to MFR & MFR to MM & AC \\
\hline Control & $3.10 \mathrm{a}$ & $28.40 \mathrm{~b}$ & $27.30 \mathrm{c}$ & $41.00 \mathrm{a}$ & $101.80 \mathrm{~d}$ \\
100 & $3.10 \mathrm{a}$ & $28.50 \mathrm{~b}$ & $31.0 \mathrm{~b}$ & $41.00 \mathrm{a}$ & $103.50 \mathrm{~d}$ \\
200 & $3.20 \mathrm{a}$ & $29.50 \mathrm{~b}$ & $33.10 \mathrm{~b}$ & $43.00 \mathrm{a}$ & $107.30 \mathrm{c}$ \\
300 & $3.10 \mathrm{a}$ & $34.20 \mathrm{a}$ & $35.40 \mathrm{~b}$ & $43.20 \mathrm{a}$ & $114.50 \mathrm{~b}$ \\
400 & $3.10 \mathrm{a}$ & $34.40 \mathrm{a}$ & $38.50 \mathrm{a}$ & $45.40 \mathrm{a}$ & $119.76 \mathrm{a}$ \\
CV & 2.10 & 8.74 & 9.78 & 4.35 & 18.10 \\
\hline
\end{tabular}

S-Sowing; MG-Massive germination; MF-Massive flowering; MFR-Massive fructification; MM-Massive maturation; ACAgronomic cycle.

Values within the same column with same letter are not significantly different at $p=0.05$ (Tukey's HSD multiple range test).

ferences among the treatments in terms of the duration of the phase until massive germination occurred.

However, there was a significant increase in the duration of the phase until the massive flowering of the plants occurred among the plants that received the highest concentrations of QuitoMax (300 and $400 \mathrm{mg} \mathrm{ha}^{-1}$ ) with respect to the rest of the treatments, including the control. Once in the stage of massive flowering until massive fruiting, only the treatment that received the highest concentration of QuitoMax showed differences from the other treatments, while the plants that received QuitoMax at any concentration underwent a significantly longer phase than the control. Additionally, no differences were found among the treatments in the mass maturation stage. However, over the duration of the cultivation cycle, the plants given the highest concentration of QuitoMax had the longest cycle of all, with a cycle of 120 days, compared to 102 days in the control. These results could be explained because the active ingredient of QuitoMax is the chitosan polymer. This polymer has the property of forming a transparent and semipermeable layer to gases on the surface of the leaves, causing moisture retention and stomatal closure (Irriti et al., 2009), and the temperature of the plant leaves was therefore also decreased. Since cumulative temperature is one of the main factors affecting the life cycle duration in plants (Valdez et al., 2012), chitosan-treated plants may have a longer life cycle than control plants.

Additionally, the application of different concentrations of QuitoMax caused significant differences in some indicators of tomato var. Pomodoro production (Table 3).

The plants treated with the highest concentrations of QuitoMax (300 and $400 \mathrm{mg} \cdot \mathrm{ha}^{-1}$ ) always had significantly better indicators in terms of the number of bunches per plant, number of fruits per bunches, fruit polar diameter, fruit equatorial diameter, fruit mass, and yield than those

Table 3. Values of some indicators of production of variety Pomodoro tomato plants treated with QuitoMax at different concentrations.

\begin{tabular}{lcccccc}
\hline $\begin{array}{l}\text { QuitoMax } \\
\text { treatments }\left(\mathrm{mg} \mathrm{ha}^{-1}\right)\end{array}$ & $\begin{array}{c}\text { Bunches per } \\
\text { plant }\end{array}$ & $\begin{array}{c}\text { Fruits per } \\
\text { bunch }\end{array}$ & $\begin{array}{c}\text { Polar diameter } \\
(\mathrm{cm})\end{array}$ & $\begin{array}{c}\text { Equatorial } \\
\text { diameter }(\mathrm{cm})\end{array}$ & $\begin{array}{c}\text { Fresh biomass of } \\
\text { the fruit }(\mathrm{g})\end{array}$ & $\begin{array}{c}\text { Yield } \\
\left(\mathrm{kg} \mathrm{m}^{2}\right)\end{array}$ \\
\hline Control & $3.8 \mathrm{~d}$ & $5.6 \mathrm{c}$ & $43.0 \mathrm{~d}$ & $57.70 \mathrm{c}$ & $120.0 \mathrm{~b}$ & $32.6 \mathrm{c}$ \\
100 & $5.2 \mathrm{~cd}$ & $5.5 \mathrm{c}$ & $49.5 \mathrm{c}$ & $57.50 \mathrm{c}$ & $123.0 \mathrm{~b}$ & $37.25 \mathrm{~b}$ \\
200 & $6.5 \mathrm{c}$ & $7.8 \mathrm{~b}$ & $52.0 \mathrm{~b}$ & $61.20 \mathrm{~b}$ & $126.0 \mathrm{~b}$ & $37.31 \mathrm{bc}$ \\
300 & $7.4 \mathrm{~b}$ & $8.4 \mathrm{~b}$ & $56.5 \mathrm{a}$ & $63.40 \mathrm{ab}$ & $132.0 \mathrm{a}$ & $42.25 \mathrm{a}$ \\
400 & $9.1 \mathrm{a}$ & $10.2 \mathrm{a}$ & $58.4 \mathrm{a}$ & $65.50 \mathrm{a}$ & $135.0 \mathrm{a}$ & $47.38 \mathrm{a}$ \\
$\mathrm{CV}(\%)$ & 6.65 & 3.52 & 7.50 & 5.45 & 5.70 & 4.25 \\
\hline
\end{tabular}

Values within the same column with same letter(s) are not significantly different at $p=0.05$ (Tukey's HSD multiple range test). 
in the control treatment. It should be noted that the application of the highest concentration of QuitoMax (400 $\mathrm{mg} \mathrm{ha}^{-1}$ ) always significantly increased the productive indicators over those corresponding to the lowest concentrations except in the cases of the two evaluated diameters, fruit biomass and yield, which did not differ from those resulting from the application of the concentration of $300 \mathrm{mg} \cdot \mathrm{ha}^{-1}$. These results may have occurred because of an increase in the chlorophyll content in the leaves and enhanced nutrient uptake in the plants treated with chitosan, as has been discussed previously. These effects may cause an increase in plant biomass and yield, as it was found in the results.

The results agree with those reported by several authors who found a stimulating effect of QuitoMax on potatoes and beans (Morales et al., 2015; 2016), showing the improvement of productive indicators in these crops when QuitoMax was applied foliarly at concentrations in the same range as that used in this work. Better production indicators have been found in different wheat varieties in association with the application of chitosan (Wang et al., 2015). All this evidence reinforces the biostimulant nature of chitosan in crops and suggests that the same effect may be occurring in tomatoes.

It was also found that the foliar application of QuitoMax causes significant improvement in the quality of tomato fruits (Table 4).

When applying the highest concentrations of QuitoMax (300 and $400 \mathrm{mg} \cdot \mathrm{ha}^{-1}$ ), a higher content of total soluble solids was found in the fruits, with significant differences between the control and the rest of the treatments. However, no significant differences were found in the acidity or $\mathrm{pH}$ of the fruits, although there was a tendency toward decreased acidity when QuitoMax was applied, which can lead to a better taste and a greater consumer acceptance of these fruits.
Table 4. Indicators of the quality of tomato fruits from variety Pomodoro tomato plants treated with different concentrations of QuitoMax.

\begin{tabular}{lccc}
\hline $\begin{array}{l}\text { QuitoMax treatments } \\
\left(\mathrm{mg} \cdot \mathrm{ha}^{-1}\right)\end{array}$ & $\begin{array}{c}\text { Total soluble } \\
\text { solids (mg, } \\
\%)\end{array}$ & Acidity & $\mathrm{pH}$ \\
\hline Control & $4.4 \mathrm{~b}$ & 0.51 & 4.2 \\
100 & $4.1 \mathrm{~b}$ & 0.48 & 4.4 \\
200 & $4.4 \mathrm{~b}$ & 0.48 & 4.2 \\
300 & $6.2 \mathrm{a}$ & 0.45 & 4.2 \\
400 & $6.4 \mathrm{a}$ & 0.44 & 4.2 \\
$\mathrm{CV}(\%)$ & 6.31 & 1.12 & 1.03 \\
\hline
\end{tabular}

Values within the same column with same letter are not significantly different at $p=0.05$ (Tukey's HSD multiple range test).

The results obtained agree with those from other studies that indicate that the application of chitosan to fruits improves their quality and extends their postharvest shelf life (Kerch, 2015; Hewajulige et al., 2015). In this sense, it is suggested that chitosan stimulates the production of enzymes and metabolites in fruits that can protect them against post-harvest diseases, which has been demonstrated in mango fruits (Gutiérrez-Martínez et al., 2017). Some of these effects have been observed in strawberry fruits even following pre-harvest foliar applications (Saavedra et al., 2016), which also occurred in this work, so such effects could occur in a similar way in tomatoes. The results obtained in terms of the productive indicators of the tomato plants treated with the different concentrations of QuitoMax show significant differences among the treatments in terms of the commercial quality of the fruits (Table 5).

Fruits from plants treated with the highest concentration of QuitoMax (400 mg $\left.\cdot \mathrm{ha}^{-1}\right)$ had the highest mass of first and second quality fruits in all treatments, while those in the third quality group did not differ from those in the treatment with the concentration of $300 \mathrm{mg} \cdot \mathrm{ha}^{-1}$. These results suggest that to obtain the best results in terms of the commercial quality of the fruits, the concentration of $400 \mathrm{mg} \cdot \mathrm{ha}^{-1}$ of QuitoMax must be used. 
Table 5. Effect of QuitoMax on the commercial quality of the fruits.

\begin{tabular}{lccc}
\hline $\begin{array}{l}\text { QuitoMax treatments }\left(\mathrm{mg} \mathrm{ha}^{-1}\right) \\
\text { Quality group }\end{array}$ & $\begin{array}{c}\text { Fruit mass } \\
1^{\text {st }}(\mathrm{kg})\end{array}$ & $\begin{array}{c}\text { Fruit mass } \\
2^{\text {nd }}(\mathrm{kg})\end{array}$ & $\begin{array}{c}\text { Fruit mass } \\
3^{\text {rd }}(\mathrm{kg})\end{array}$ \\
Control & $18.30 \mathrm{c}$ & $31.20 \mathrm{c}$ & $18.50 \mathrm{c}$ \\
100 & $18.60 \mathrm{c}$ & $42.50 \mathrm{~b}$ & $26.50 \mathrm{~b}$ \\
200 & $23.20 \mathrm{~b}$ & $43.60 \mathrm{~b}$ & $27.20 \mathrm{~b}$ \\
300 & $26.40 \mathrm{~b}$ & $43.40 \mathrm{~b}$ & $31.66 \mathrm{a}$ \\
400 & $28.30 \mathrm{a}$ & $52.45 \mathrm{a}$ & $33.20 \mathrm{a}$ \\
CV $(\%)$ & 9.86 & 12.18 & 16.20 \\
\hline
\end{tabular}

Values within the same column with same letter are not significantly different at $p=0.05$ (Tukey's HSD multiple range test).

The main conclusions are as follows. The highest concentrations of QuitoMax (300 and $400 \mathrm{mg}$ $\left.\mathrm{ha}^{-1}\right)$ resulted in the production of more vigorous plants than the lower doses and the control treatment. In the treatments with these concentrations, the duration of all vegetative and reproductive phenological phases were longer except for the massive fructification phase at maturity. These same concentrations of QuitoMax also resulted in the highest values in the production indicators, including the fresh biomass of the fruits and yield, and they also provided fruits of better nutritional quality with significantly higher contents of total soluble solids and a tendency towards a lower degree of acidity, which favors their better flavor and a consumer acceptance.

\section{Resumen}

J.J. Reyes-Pérez, E.A. Enríquez-Acosta, B. Murillo-Amador, M.A. Ramírez-Arrebato, A.T. Rodríguez-Pedroso, R. Zulueta-Rodríguez, y L.G. Hernández-Montiel. Respuesta fisiológica, fenológica y productiva del tomate (Solanum licopersicum L.) tratado QuitoMax 2018. Cien. Inv. Agr. 45(2): 120-127. El objetivo de este estudio fue evaluar la aplicación foliar del bioestimulante QuitoMax a las concentraciones 100, 200, 300 y 400 $\mathrm{mg} \cdot \mathrm{ha}^{-1}$ en comparación a un testigo sin aplicación sobre la altura y el grosor del tallo de plantas de tomate, también se evaluó la duración de las fases fenológicas de las plantas, los indicadores productivos: número de racimos por plantas, frutos por racimos, diámetro polar y ecuatorial del fruto, la masa del fruto y el rendimiento agrícola, así como la calidad del fruto expresada en sólidos solubles totales y nivel de acidez, adicionalmente se evaluó la calidad comercial de los frutos cosechados. Se encontró que las mayores concentraciones de QuitoMax 300 y 400 (mg $\mathrm{ha}^{-1}$ ) produjeron las plantas más vigorosas, alargaron la duración en las fases fenológicas, pero produjeron significativamente los mayores valores en los indicadores de producción incluidos la masa fresca de los frutos y el rendimiento. Adicionalmente propiciaron frutos con mayor contenido de sólidos solubles totales

Palabras claves: Bioestimulante, hortaliza, Quitosana. 


\section{References}

Díaz-Leguizamón, J.J., O.F. Chingaté-Cruz, A.D. Sánchez-Reinoso, and H. Restrepo-Díaz. 2016. The effect of foliar applications of a bio-stimulant derived from algae extract on the physiological behavior of lulo seedlings (Solanum quitoense cv. Septentrionale). Cien. Inv. Agr. 43:25-37.

Durand, J., M. Riera, A. Fernández, and J. Goulet. 2013. Respuesta del tomate al uso de alternativas orgánicas y micorriza en producción protegido en Guantánamo. Centro Agrícola 40:15-21.

Espinosa, K., and M. Molina. 2015. Evaluación agronómica de hortalizas de hoja, col china (Brassica campestris) y perejil (Petroselinum crispum) con fertilizantes orgánicos. UTCiencia 2:29-34.

FAO 1997. Lucha Contra la Contaminación Agrícola de los Recursos Hídricos. (Estudio FAO Riego y Drenaje - 55) M-56 ISBN 92-5-303875-6. http://www.fao.org/docrep/W2598S/w2598s00. htm\#Contents (accessed 20 Jun. 2018).

Freshplaza. 2016. Datos de la I Conferencia Internacional de Tomate. www.freshplaza.es/.../La-producción-mundial-de-tomates-alcanza-los 130millones-de-tonelada. (accessed 23 Sep. 2017).

Gutiérrez-Martínez, P., S. Bautista-Baños, G. Berúmen-Varela, A. Ramos-Guerrero, and A.M. Hernández-Ibañez. 2017. Response in vitro of Colletotrichum to chitosan. Effect on incidence and quality on tropical fruit. Enzymatic expression in mango. Acta Agronómica. 66:282-289.

Hewajulige, I., N. Wilson, R.S. Wijeratnam, M. Perera, and S. Fernando. 2015. Extending storage life of commercially important tropical fruits using bio-waxes. Acta Horticul. 1091:283-290.

Irriti, M., V. Picchi, M. Rossoni, S. Gomarasca, N. Ludwing, M. Garganoand, and F. Faoro. 2009. Chitosan antitranspirat activity is due to abscisic acid dependent stomatal closure. Env. Exp. Bot. 66:493-500

Kerch, G. 2015. Chitosan films and coatings prevent losses of fresh fruit nutritional quality: A review. Trends Food Sci. Technol. 46:159-166.

Malerba, M., and R. Cerana. 2016. Chitosan Effects on Plant. Systems. Int. J. Mol. Sci, 996:1-15.
Márquez-Hernández, C., $\mathrm{P}$ Cano-Ríos., U. Figueroa-Viramontes, J.A. Avila-Diaz, N. Rodríguez-Dimas, and J.L. García-Hernández. 2013. Rendimiento y calidad de tomate con fuentes orgánicas de fertilización en invernadero. Revista Internacional de botánica experimental 82:55-61.

Martínez, L., I. Castro, L. Díaz, and M. Núñez. 2007. Influencia del tratamiento a semillas con quitosana en el crecimiento de plantas de tomate (Solanum lycopersicum L.) Cultivos Tropicales 28:79-82.

Morales, D., J. Dell Amico, E. Jerez, Y. Díaz, and R. Martín. 2016. Efecto del QuitoMax ${ }^{\circledR}$ en el crecimiento y rendimiento del frijol (Phaseolus vulgaris L.). Cultivos Tropicales 37:142-144.

Morales, D., L. Torres, E. Jerez, A. Falcón, and J. Dell Amico. 2015. Efecto del QuitoMax en el crecimiento y rendimiento del cultivo de la papa (Solanum tuberosum, L.). Cultivos Tropicales 36:133-143.

NTE. 2014. INEN1909 FRUTAS FRESCAS. TOMATE DE ÁRBOL. REQUISITOS código ICS: 67.080 http://www.normalizacion.gob.ec/ wpcontent/uploads/downloads/2014/02/nte inen_1909_2r.pdf(accessed 12 Nov. 2017).

Pichyangkuraa, R, and S. Chadchawanb. 2015. Biostimulant activity of chitosan in horticulture. Sci. Horticul.196:49-65.

Rodríguez-Pedroso, T., M. Plascencia-Jatomea, S. Bautista-Baños, M. Cortez, and M. RamírezArrebato. 2016. Actividad antifúngica in vitro de quitosanos sobre Bipolaris oryzae patógeno del arroz. Acta Agron, 65:98-103.

Rodríguez-Pedroso, A., M. Ramírez-Arrebato, A. Falcón-Rodríguez, S. Bautista-Baños, E. Ventura-Zapata, and Y. Valle-Fernández. 2017. Efecto del Quitomax ${ }^{\circledR}$ en el rendimiento y sus componentes del cultivar de arroz (Oryza sativa L.) var. INCA LP 5. Cultivos Tropicales, 38(4):156-159.

Saavedra, G.M, N.E. Figueroa, L.A. Poblete, S. Cherian, and C.R. Figueroa. 2016. Effects of preharvest applications of methyl jasmonate and chitosan on postharvest decay, quality and chemical attributes of Fragaria chiloensis fruit. Food Chem. 190:448-453. 
Salachna, P, and Zawadzińska, A. 2014. Effect of chitosan on plant growth, flowering and corms yield of potted freesia. Journal of Ecological Engineering 15(3):97-102.

StatSoft Inc. 2011. Statistica. System reference. StatSoft, Inc., Tulsa, Oklahoma, EUA.

Valdez, J.B., F. Soto, T. Osuna, and M.A. Baez. 2012. Phenological prediction models for white corn
(Zea mayz L.) and fall armyworm (Spodoptera frugiperda J. E. Smith). Agrociencia 46:399-410. Wang, M., Y. Chen, R. Zhang, W. Wang, X. Zhao, Y. Du, and H. Yin. 2015. Effects of chitosan oligosaccharides on the yield components and production quality of different wheat cultivars (Triticum aestivum L.) in Northwest China. Field Crops Res. 172:11-20. 